УДК (628.28)

\title{
Т.М. МКРТЧЯН
}

аспирант факультета инженерно-экодогических систем кафедры водоснабжения и водоотведения Ростовский государственный строительный университет

\section{НОВОЕ УСТРОЙСТВО ДДЯ ИЗМЕРЕНИЯ ОСАДКОВ В СЕТЯХ ВОДООТВЕДЕНИЯ}

A NEW DEVICE FOR THE MEASUREMENT OF SEDIMENT IN THE WASTEWATER NETWORK

Представлен анахиз определения степени заиления колиекторов самотечных систем водоотведения. Описаны трудоемкость и санитарная опасность процесса, а также погрешность методов измерения высоты слоя осадков, применяемых в настоящее время.

Разработано новое практичное устройство для измерения осадков и наполнения сточных вод в сетях водоотведения, погрешность которого составляет 1-2 мм. Устройство транспортабельное и простое в применении, его можно изготовить в мастерских экспхуатирующих организаций.

Ключевые слова: осадок, устройство, измерение, высота слоя, лоток, наполнение, водоотводящая сеть.

В современных условиях, когда ужесточены экологические и санитарные требования, применяются штрафные санкции к эксплуатирующим организациям вследствие выхода бытовых сточных вод на поверхность в населенных пунктах. Поэтому при составлении графиков планово-предупредительных работ службы эксплуатации уделяют особое внимание таким участкам сетей водоотведения, где наблюдается заиление. Для очистки сетей составляется журнал, в котором указывается состояние очищаемых трубопроводов, чтобы служба очистки могла применять соответствующие технологии и средства [1].

Для определения степени заиления необходимо измерить высоту слоя осадка в трубах. На практике эксплуатационники в основном до сих пор верхнюю границу грязевого слоя определяют вручную или штангой и с большими откдонениями измеряют его высоту. Для этого нужно погружать руки в сточную жидкость, что небезопасно в санитарном отношении.

С целью упрощения измерительного процесса нами [4] разработано простое измерительное устройство, с помощью которого удобно измерить толщину грязевых отложенный в сетях (рис. 1).
An analyses of data of determine sediment degree in wastewater collector has been introduced in the article. Described the difficulty of process and measurement tolerance of the sediment at present time.

A new practical equipment for measuring sediments and filling of wastewater in the sewage networks has been provided and developed. Equipment's measurement tolerance is 1-2 $\mathrm{mm}$. The equipment is portable and easy to use in practice. Also it can be made and fix in the sewage workshops.

Keywords: sediment, equipment, measurement, filling, half section sewer, wastewater network.

Устройство состоит из нержавеющей трубки диаметром 15 мм, нижний конец которого выполнен в виде сверла с целью его иегкого прохождения через осадок. На верхнем конце трубки устанавдивается съемная головка, с помощью которой трубка через плотный слой осадка докручивается до дна дотка. Два крыла головки обеспечивают горизонтальное подожение и дают возможность удерживать трубку в вертикальном положении. На трубке имеется миллиметровая измерительная шкала. (Маркировка шкалы может быть выполнена светящейся, чтобы в полумраке канадизационных колодцев ее можно было видеть без лампы).

Дия измерения высоты слоя осадка на трубке устанавдивается передвижное измерительное приспособление, состоящее из металдического патрубка диаметром 16 мм и жесткого основания толщиной 1,5-2,0 мм. Эти два элемента имеют резьбовое соединение и с целью легкого транспортирования могут быть разделены. Приспособления к трубке крепятся винтом. На приспособлении предусмотрено окно для считывания показаний измерений. С его помощью определяется относительное смещение измерительного приспособления по высоте трубки. 

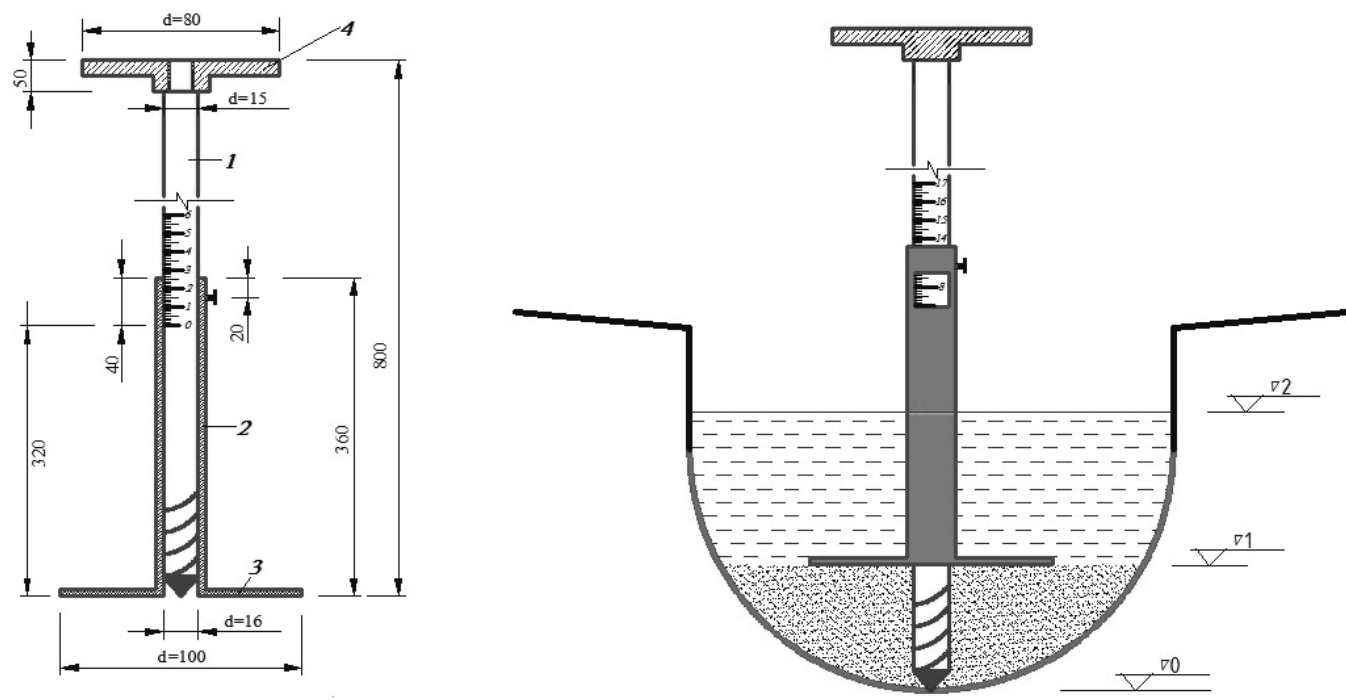

Рис. 1. Устройство для измерения осадка:

1 - металлическая трубка; 2 - измерительное приспособление; 3 - дисковое основание; 4 - головка

Основание приспособления выполнено в виде диска диаметром 100 мм, оно обеспечивает наименьшее сопротивление в направлении потока сточных вод в канале и при легком нажиме не входит в грязевой слой на дне канала. Такое решение не приводит к завихрению и нарушению потока, в результате чего осадок под основаниям не размывается, что могио бы привести к искажению результата измерения. Измерительная шкала расположена на трубке таким образом, чтобы указатель стоял на нуле шкалы, когда нижний конец трубки находится на одном уровне с дисковым основанием. Конструкция головки измерительного устройства позводяет подвешивать прибор на крюк-карабин и пояс обслуживающего персонала, чтобы у него были свободны руки при подъеме из колодца $[2,3]$.

При измерении высоты слоя осадка трубку необходимо устанавдивать на центрадьной оси лотка в смотровом колодце и вкручивать ее до дна лотка. С помощью крыльев головки трубка во время измерения поддерживается в вертикальном положении. Приспособление медленно опускается в сточную воду до его прикасания с поверхностью осадка. В этом положении укрепляется винт и по шкале берется показание, которое соответствует высоте слоя осадка.

С помощью данного устройства возможно определить также наполнение сточных вод в дотке. Для этого измерительное приспособление поднимается выше уровня воды и медленно опускается до поверхности сточной воды. В этом положении измеряется отметка поверхности и определяется наполнение лотка.
Необходимо отметить, что вместо традиционной мерной штанги дисковое основание при измерении сглаживает волны и подпоры на поверхности жидкости, в резудьтате чего повышается точность измерения, которая составляет 1-2 мм.

\section{Выводы:}

1. Прибор представдяет собой простое устройство без быстро изнашиваемых и сложных элементов.

2. Изготовление прибора возможно в мастерских эксплуатирующих организаций для применения его при эксплуатации сетей водоотведения.

3. С помощью предложенного устройства можно с большой точностью определить наполнение сточных вод в Аотке.

\section{БИБЛИОГРАФИЧЕСКИЙ СПИСОК}

1. Эксплуатация систем водоснабжения, канализации и газоснабжения: справочник [Текст] / под ред. В.Д. Дмитриева. - М.: Стройиздат, 1988.

2. Правила технической эксплуатации систем и сооружений коммунального водоснабжения и канадизации. МДК 3-02.2001.

3. Свод правил. СП 32.1330.2012. Канализация. Наружные сети и сооружения, Актуализированная редакция СНиП 2.04.03-85. [Текст] - М., 2012.

4. Патент на полезную модель 123929. Устройство для измерения высоты слоя осадков в кододцах канализационной сети. Опубликовано 10.01.2013 [Текст] / Н.С. Серпокрылов, Т.М. Мкртчян.

(C) Мкртчян T.M., 2013 